\title{
Profile of Professionals of the Brazilian Production Sector of Timber Housing ${ }^{1}$
}

\author{
Victor DE ARAUJO ${ }^{2, \dagger}$ - Cesar POLANCO ${ }^{3}$ Elen MORALES $^{4}$ •

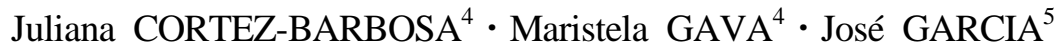

\begin{abstract}
On account of the lack of education of Brazilian worker, this paper analyzed the characteristics of those professionals working in the production sector of timber houses. A sectoral survey was carried out with respective entrepreneurs to investigate the available professionals (career and contract types), evaluate the demands of skilled workers, and indicate solutions to improve the quality of labor qualification. Similarly, over $65 \%$ of sampled producers presented both direct-hired and outsourced workforce. For such contract ways, Civil Engineers and Architects were the main careers. Carpenters, Civil Engineers and Architects experienced on timber were the main sectoral demands. Timber Engineers have good potentials of service for this sector. The creation of courses on timber products can emerge as a key alternative to train people.
\end{abstract}

Keywords: civil construction, wooden house, sectoral research, personal interview

\section{INTRODUCTION}

Planted-forest production chain is featured by product diversity, which involves a set of activities such as sylviculture, harvesting, and wood transformation to manufactured products (França et al., 2016), which include furniture, building, decoration, panels, tools, toys, boxes, and other items (De Araujo et al., 2017).

The operational planning represents an indispensable service for a competitive forestry industry, due to its priorities and strategies for profitable outcomes (Campos et al., 2013). High skilled labor is related to higher forest productivity indexes (Coelho and Coelho, 2013). The strategy establishment is essential to measure and compare the production performances in the foresttimber industry (Fiorentin et al., 2017). Thereby, trained professionals are required to reach good levels from planning to processing.

In Brazil, sawn wood industry has presented relatively low investments in technology and qualification labor, in reason of lower yield and efficiency in the conversion of wooden logs into lumber (Longue and Colodette,

\footnotetext{
${ }^{1}$ Date Received June 10, 2019, Date Accepted August 14, 2019

2 Department of Forest Sciences, Luiz de Queiroz College of Agriculture, University of São Paulo, Piracicaba 13418-900, Brazil

${ }^{3}$ Faculty of Environment and Natural Resources, Francisco José de Caldas District University, Bogotá 110321, Colombia

4 Timber Industrial Engineering Graduation Course, Campus of Itapeva, São Paulo State University, Itapeva 18409-010, Brazil

${ }^{5}$ Department of Forest Sciences, Luiz de Queiroz College of Agriculture, University of São Paulo, Piracicaba 13418-900, Brazil

$\dagger$ Corresponding author: Dr. Victor De Araujo (e-mail: victor@usp.br, ORCID: 0000-0002-2747-4738)
} 
Victor De ARAUJO • Elen MORALES • Juliana CORTEZ-BARBOSA • Maristela GAVA • José GARCIA

2013). For Clement and Higuchi (2006), those reasons could explain why Brazilian lumber is mostly internally marketed, while this material has not been applied in noble and profitable applications.

Wood provides greater economic profitability even for primary production industry - such as in Swedish sawmills - as long as there are more integrations with secondary productions for added-value products (Brege et al., 2010). For example, cabinets, flooring and millwork fixtures with higher-value lumber have relevant markets on housing industry in the United States (Buehlmann et al., 2017). But, timber products are underused in Brazil for durable purposes such as buildings. According to Frigo and Silveira (2012), Brazilian construction industry has focused on artisanal masonry techniques, due to a highly disqualified workforce; this low qualification is an obstacle and contributes to greater costs, inefficient processes, etc.

With the slow industrialization on 1950s, Brazilian industry started prefabricating houses from lumberproducing sawmills and primary companies (De Araujo et al., 2016). Brazilian timber housing sector has presented simplified productions supported by recent compact machinery and low-cost equipment. Today, small-scale producers have predominated this sector, which employs about 3,700 workers and represents $1 \%$ of local timber industry. (De Araujo et al., 2018a,b). This status differs from the local forestry reality.

Several studies on timber housing were developed to support more comfort and use potentialities such as O’Connor et al. (2004), Roos et al. (2010), Qu et al. (2012), De Araujo et al. (2016, 2018c), Chang et al. (2017), Kim et al. (2017), Kuzman and Sandberg (2017), Pang et al. (2017), Seo et al. (2017), etc.

Wood-based constructions could be better developed in Brazil using European strategies. Kuzman and Sandberg (2017) suggested that long-term cooperative programs with lobbying efforts and promotional campaigns are needed to increase the use of traditional and wooden products suited for contemporary architecture; to be efficient in this effort, Brazil will require skilled professionals focused on timber uses.

During 2015, Brazilian forestry sector invested around US\$ 4.0 million in professional training for the education and culture fields, whose amount provided scholarships and teaching materials for 190,000 people (IBÁ, 2016). The expansion of this initiative - whether from public and private powers - should improve the quality of workforce formation and training, particularly, on wood-based products. Technical experience and scientific knowledge from training and formation courses could represent good ways to train professionals in the Wood Science topics suitable for labor and academic aims, respectively.

Due to the reality of Brazilian worker education, this study aimed to identify the workforce characteristics of local timber house producers such as present careers and demands. Four hypotheses were formulated: many producers have directly hired skilled workforce; worker outsourcing is as popular as direct job; civil engineer and architect were the main careers; and, timber engineers are further promising for this sector.

\section{MATERIALS and METHODS}

\subsection{Approach, area of data collection and initial considerations}

Forest-timber chain still requires studies to supply information about its main characteristics within the Brazilian perspective. Thus, an extensive research was established to evaluate timber housing industry, due to the lack of data and discussion about product, corporate and sectoral aspects. This research was established by a sectoral survey with divided topics, whose center lines involved distinct information to assist on the creation of policies for sectoral development. For this, face-to-face interviews were carried out to 
collect data through a semi-structured questionnaire directed to entrepreneurs of the Brazilian timber housing production sector. In view of the lack of information and sectoral association absences, these companyowners were initially prospected and listed through a methodology based on corporate website searching. For the performance of this research, such solution was indispensable, while there is no official association to represent wooden housing sector in Brazilian scenario, which has restricted its information access and disclosure. Therefore, the evaluation of trained professionals was the main side view observed in this paper, particularly, from timber housing producers located in the Brazilian territory. In view of a better performance concerning research costs, the studied area included the Southern states, due to an expressive producer concentration, that is, $92 \%$ of the sector (De Araujo et al., 2018a,b,c).

\subsection{Questionnaire preparation, data collection, and response analysis}

Questionnaire development involved four stages. Design and preparation were performed using preceding versions, which were led by first author and supervised by last author. Correction and expansion stages were performed to refine the questionnaire for an accurate, understandable and assertive model. After two short pretests, third version was definitely selected by the managing group (manager, advisor, academics, and professionals). This process was the same applied for De Araujo et al. (2018a,b,c) in other views.

Seven questions were developed exclusively for this sectoral side view on workforce characterization:

1) Does your company hire any professionals? - with dichotomous answers: yes, no;

2) If affirmatively on query 1 , which professionals does your company hire? - with hybrid answers: architect; civil engineer; wood industrial engineer; administrator; electrical engineer; production engineer; mechanical engineer; environmental engineer; safety engineer; logistics technologist;

3) Does your company outsource any professionals? - with dichotomous answers: yes, no;

4) If affirmatively on query 3 , which professionals does your company outsource? - with hybrid answers: architect; civil engineer; wood engineer; administrator; electrical engineer; production engineer; mechanical engineer; environmental engineer; safety engineer; logistics technologist;

5) Which professionals does your company require? - with open answers;

6) Do you know Wood Industrial Engineering course, whose focus is wood industrialization in products? - with dichotomous answers: yes, no;

7) Would you hire a Wood Industrial Engineer for your company? - closed single-answers: no; yes; yes, if there is demand; already hire this professional.

Then, queries 2 and 4 had hybrid answers to allow the insertion of unlisted responses. These queries were only applied to interviewees whether previous queries (1 and 2) were solely affirmative.

All questions included qualitative responses, whose entrepreneur responses were converted to percentage. A margin of error was obtained to certify this sampling. This validation was calculated by the statistical software Raosoft (2004). This margin of error was designed from sampling and full population, for $95 \%$ confidence level and 50\% response distribution as prescribed by Raosoft (2004). Survey sampling can be validated or rejected according to levels suggested by the literature. After phone invitations, face-to-face interviews were carried out by the manager, depending only on the availability and motivation of studied entrepreneurs. Data analysis was led by the whole managing group (De Araujo et al., 2018a,b,c). 
Table 1. Involved populations and statistical perception of collected data

\begin{tabular}{|c|c|c|}
\hline & Producer (amount) & Margin of Error (\%) \\
\hline Overall estimated population of timber housing sector & $210^{\text {(a) }}$ & - \\
\hline Acceptable level for sampling & $66^{(\mathrm{c})}$ & $10.00( \pm 5.00)^{(b)}$ \\
\hline Ideal level for sampling & $136^{\text {(c) }}$ & $5.00( \pm 2.50)^{(b)}$ \\
\hline Interviewed producers of this analyzed sector & $107^{(\mathrm{a}, \mathrm{c})}$ & $6.65( \pm 3.33)^{(\mathrm{a}, \mathrm{c})}$ \\
\hline
\end{tabular}

\section{RESULTS and DISCUSSION}

From a broad survey, this paper and other approaches characterized the Brazilian timber housing sector. The present study featured every professional from this sector. Table 1 showed the margins of error cited by literature and performed here as well as the estimation of local producers - whose size is considerable.

In relation to the service modality for every professional in the Brazilian industry, two ways are possible: outsourced and hired contracts. While outsourcing is a service transfer from the main company for any third parts or companies, the direct hiring is the way to officially work under registration by an enterprise. Pereira Filho and Lucena Filho (2016) cited that this model was considered because labor outsourcing is a reality in the Brazilian industry and, particularly, popular in construction.

In the first and third questions, direct hiring (Fig. 1a) and outsourcing (Fig. 1b) of professionals were identified on industrial (off-site) and on-site scopes of house production. Similar scenarios were found for both job contract types (Fig. 1a,b), because these examples surpassed $65 \%$ ( $\pm 3.33 \%$ of the margin of error) in this sampling $(\mathrm{n}=107)$. First hypothesis was accepted, because two-thirds of producers have directly hired workers (Fig. 1a). From affirmative responses in these queries, the second and fourth questions (Figs. 2 and 3) detailed the worker categories, both in service (hired and outsourced workers) and in current demand by these

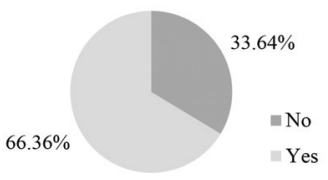

(a)

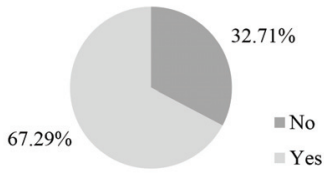

(b)
Fig. 1. Professional presence from $(n=107)$ : (a) direct hiring and (b) outsourcing.

sampled companies, respectively.

In the status verified in the second and fourth questions (Fig. 2), the presence of direct-hired people did not differ perceptibly from outsourced workers in all 20 categories. This situation was possible because the difference between the statuses (hiring/outsourcing) in a same category was always within the margin of error $( \pm 3.33 \%)$. Due to this status similarity by category, the second hypothesis was also certified.

About those professionals available, directly and indirectly, by the studied producers of timber houses, the second and fourth queries also identified 20 career categories (Fig. 2), among which 15 full graduation courses composed such listing. Around $60 \%$ of these graduated professionals have a diploma of Bachelor in Engineering for 11 different fields. Administration, Architecture, Law and Biology were further cited. Other two additional categories were formed by three technological and two technical courses.

Four professionals mentioned by the interviewees have expertise on civil construction (Civil Engineers, Architects, Electrical Engineers, and Building Techni- 


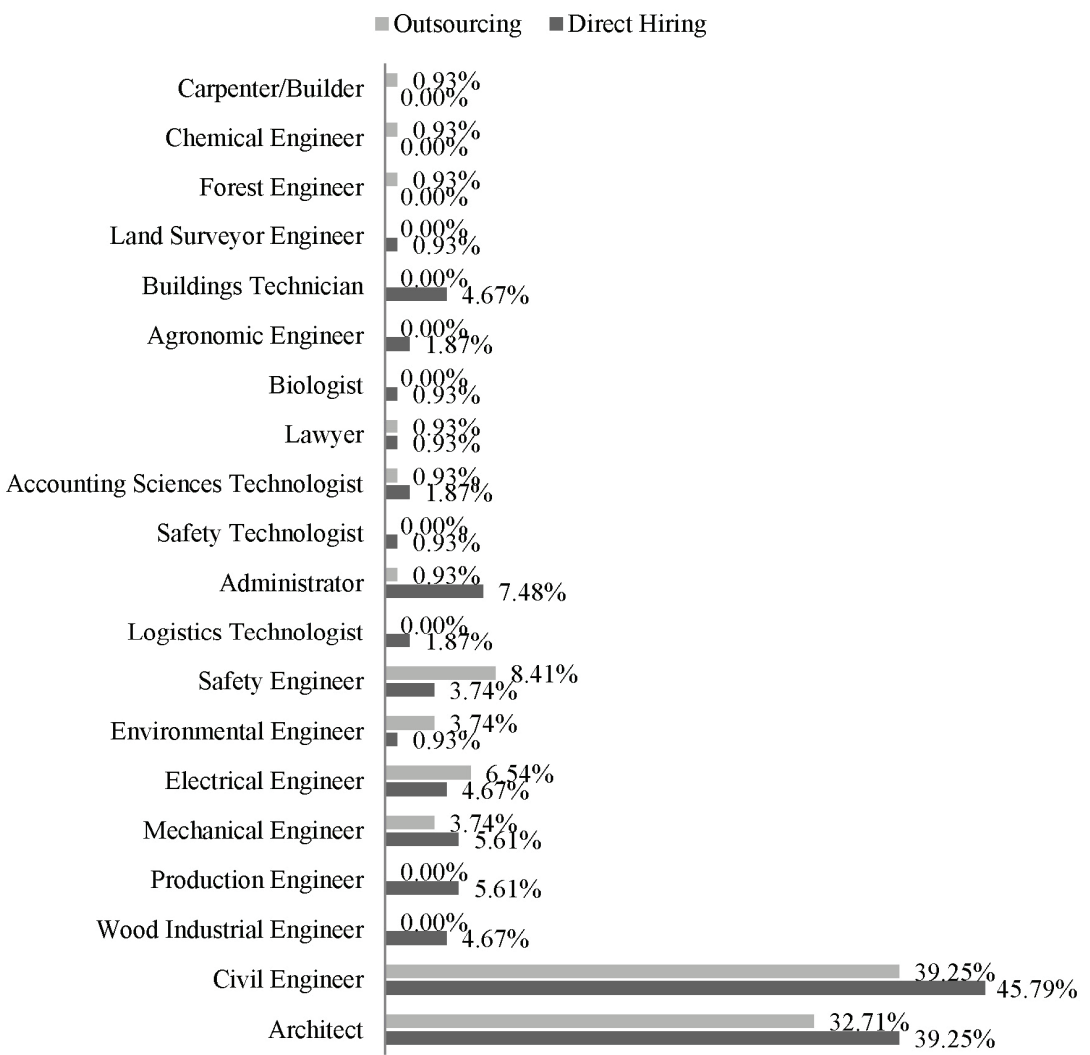

Fig. 2. Description of professionals in service in the evaluated companies $(\mathrm{n}=107)$.

cians) and two of them in timber-based applications and constructions (Wood Industrial Engineers and Forest Engineers), being that the Builders/Carpenters have relevant experiences in these two cited fields. In addition, Civil Engineers and Architects were the most popular professionals within this sector (Fig. 2), concerning with the third hypothesis proposed.

Then, fifth question analyzed the main professional demands. About $85 \%$ of these producers declared the need for additional professionals, while only $15 \%$ did not reveal the demand for more workers (Fig. 3).

About 23 professionals were cited as potential demands for the interviewees, being that 15 professionals were directly linked to civil construction; in other words, such field includes the main needs of this sector. Most producers required Carpenters/Builders (Fig. 3), despite its low presence in this present moment (Fig. 2). Four low skilled professionals (Electrician, Plumber, Plaster Applicator, and Mason) presented similar demands to graduates in Civil Engineering and Architecture. Noticeable demands were noted by Wood Industrial and Production Engineers. Also, painters were quite required by this sector (Fig. 3).

Sixth and seventh queries were directed to understand the popularity of Timber Engineer. About 35\% of producers declared to know the existence of Wood Industrial Engineering (or Timber Engineering) in the sixth query, while other $65 \%$ ignored this intrinsic formation to this sector. In the case of these $65 \%$ of sampled producers who ignored this course, the inter- 


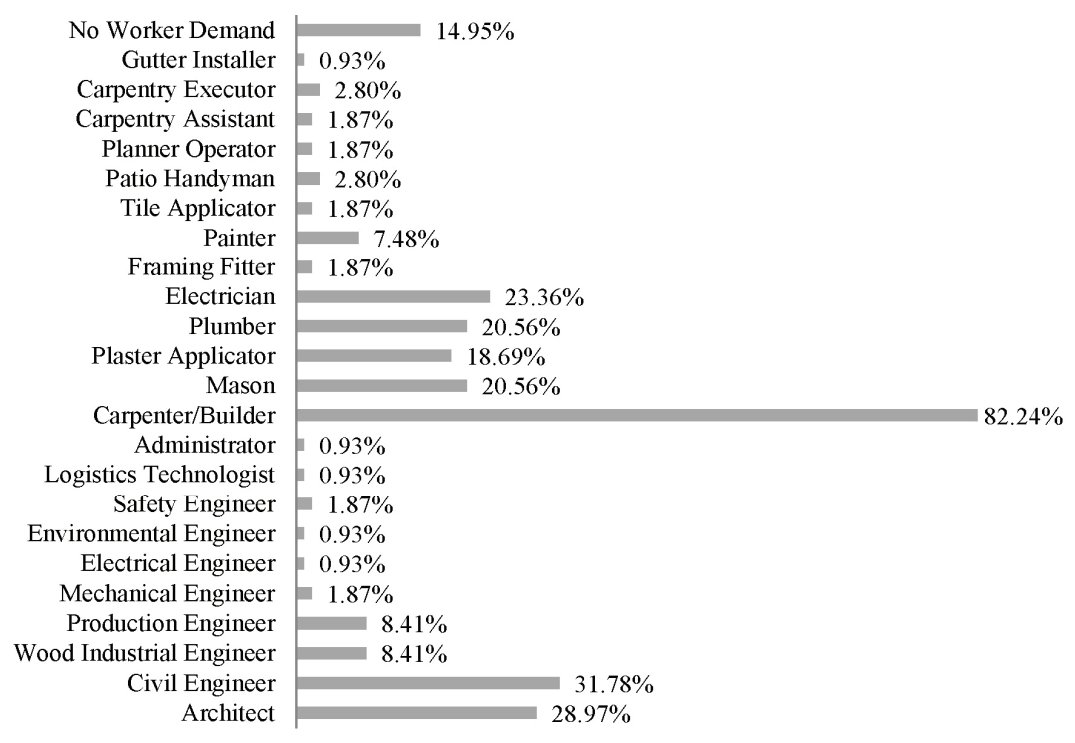

Fig. 3. Professional demands for evaluated companies $(\mathrm{n}=107)$.
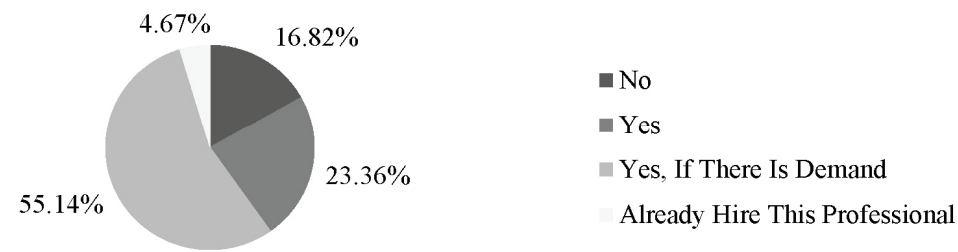

Fig. 4. Corporate motivation about the hiring of Wood Industrial Engineers $(n=107)$.

viewer briefly explained about the same occupation.

After this clarification, the seventh question showed that Wood Industrial Engineers (Timber Engineers) would be easily recruited by more than $78 \%$ of the entrepreneurs (Fig. 4). This scenario complied with the fourth hypothesis, which declared that this professional could be promising for timber house industry. Almost $5 \%$ of sampled companies declared the existence of this professional in their production lines by direct hiring. Less than $17 \%$ of producers declared no intentions to hire Timber Engineers (Fig. 4).

A considerable sampling was observed (Table 1), and considered for other approaches (De Araujo et al., 2018a,b,c), being validated by a margin of error close to $5 \%$ ideal level as cited by Pinheiro et al. (2011).

A noticeable portion over $30 \%( \pm 3.33 \%)$ still did not have any type of skilled worker (Fig. 1a,b). This representation is not appropriate for this sector, because skilled workers could contribute with experience and knowledge. More graduated and trained professionals will be available for the job market, and then, this parcel will be reduced overtime. This is justified by Weska et al. (2012), because Brazil experienced a higher education proliferation since 2003, whose student vacancies in universities doubled in a decade.

Regarding professionals from timber housing production sector, Civil Engineering and Architecture were the most popular careers in Brazil (Fig. 2), with 
a slight advantage for those Engineers; this fact is justified by additional Engineering services in structural calculation and electrical-hydraulic provisions, because the architectural design is an essential attribution for both graduations in construction. Therefore, this greater presence was an expected fact because Architects and Civil Engineers are main professionals from construction industry. In contrast, Kozak and Cohen (1999), O’Connor et al. (2004), Roos et al. (2010), Qu et al. (2012), Kuzman and Sandberg (2017) and other authors revealed that timber buildings have concentrated a limited popularization in order to professional attitudes regarding wood utilization. However, the need of timber-experienced actors is justified by Pang et al. (2017), which stated that each timber building could be significantly different by its designer and developer, because the construction envelop could be constructed in different ways using variety of wooden materials.

Safety, Electrical, Mechanical and Environmental Engineers, and Administrators were also present for both direct and indirect job contracts. Production and Wood Industrial Engineers under direct hiring jobs individually concentrated shares greater than 5\%, reflecting on new ways to find production specialists on timber scope. Agroforestry courses did not represent consolidated presences (Fig. 2), because they are mostly required for raw material production such as forest management, sylviculture and wood supply.

In the topic of worker lacking within this sector, Fig. 3 showed that there are several current demands, because 23 different professionals are further required, both from graduated and technical formations.

Based on heavy manual tasks (masons, plumbers, electricians, painters and plaster applicators), these lowskilled professionals showed visible demands (Fig. 3), despite lower qualifications. In this case, short courses could support the formation for such heavy-work activities, aiming to improve the service quality.

The main demand was focused on important technical level professional, despite its low formation index in Brazil, which was characterized by Carpenter or Builder of wooden houses. This lack was required by more than $80 \%( \pm 3.33 \%)$ of sampling. Thus, for example, the Ministry of Education (MEC) through their public technical colleges has indispensable challenge to expand this training on wooden crafts (Fig. 3). Some strategic plans could be implemented in such public institutions from technical courses based on two practical modules. For example, the first module could be focused on wood processing for furniture production. Thus, an internship could certify and graduate the professional in joinery field, whose tasks are more simplified, due to working with smaller raw materials. In addition, the second module could be directed to produce wooden parts for construction and building manufacture and assembly. From this, a second internship could consolidate a complete technical formation in carpentry for this professional. A great advantage of this training proposal would be the flexibility of labor market, since both furniture and construction manufacturers would be the main woodworking-skilled labor absorbers, that is, hirers. While wooden roofing is applied for masonry houses, such producers/contractors emerge as potential employers.

In relation to the possible locations for the installation of these carpentry-joinery centers, those regions with higher concentrations of forest-timber activities could be first destination, that is, from Southern and Southeastern states. As a timely suggestion, Brazilian furniture poles could be included on this strategy.

Despite the popularity of direct hired and outsourced employees, the Civil Engineers and Architects still represent a perceptible demand for this studied sector (Fig. 3), especially in relation to professionals with timber construction expertise, which have been unsuccessfully requested by this sector. The insertion of disciplines about timber housing contexts could be a factor to aggregate knowledge. The creation and in- 
stallation of modern post-graduation courses in timber architecture and construction could emerge as additional alternatives of professional training to be simultaneously developed in Brazil.

Those professionals trained and graduated in industrialization processes - for example, Wood Industrial Engineering (Timber Engineering) and Production Engineering - are also required by several companies (Fig. 3), especially those focused and/or with a future focus on larger scale production. While Timber Engineers have strong academic workload on timber construction and wood industrialization, Production Engineers still require the insertion of disciplines on building prefabrication and wood processing.

The workforce training for material conversion into higher added-value manufactured products becomes an important future challenge. Then, both the Brazilian Ministry of Education and Culture (MEC) and the Coordination of Personal Improvement from Higher Education (CAPES) should stimulate local public universities to eradicate demands, which have focus strategically on higher quality building production in this nation with expressive housing shortage. In the same way of carpentry courses previously proposed here, the worker formation should also be established by those cited Brazilian public educational agencies for regions with greater infrastructure and construction demands and new cities to receive future poles.

The demand of agroforestry professionals was lower in view of the local existence of a consolidated chain for the production of wood (Fig. 3), which has efficiently supplied the industry with this raw material. Forest Engineers could also be required to assist the sectoral demand, because they are somewhat capable to play roles in the forest product production. According to the MEC (2019), several public and private universities have already offered this formation in the all five Brazilian regions.

Regarding to professionals with more expertise about timber housing, that is, Wood Industrial Engineers (Fig. 3), Brazil already offers this course in four different states such as São Paulo, Paraná, Rio Grande do Sul and Espírito Santo as certified by MEC (2019). Greater absences of Wood Industrial Engineering courses are located in other states - Santa Catarina, Minas Gerais, Mato Grosso do Sul, Acre, Pará, etc. - which has also important business from forest and timber-product productions.

However, this modern course for timber industrialization still requires disclosure to clarify population and actors from construction and industry. This statement could be supported by the visible amount of studied producers that ignored the Wood Industrial Engineering course until the moment prior to this research. While $65 \%$ of interviewees only were aware about this formation by an elucidation from the interviewer, there is the need to explore and elucidate this graduation course for timber industry and the whole society.

Additional studies could be performed to evaluate this scenario over the next decades and/or designed for other different activities, considering that the real lack of information about such industrial topics.

\section{CONCLUSION}

Most of timber house producers hire skilled professionals in Brazil, both from directly and indirectly, that is, outsourced and direct hired examples. Anyway, this sector has distinct professionals working with its producers. Thus, the Engineering, Architecture, and Industrial Production were the most frequent fields of this sector. The importance of sectoral demands should be related to the direction of governmental action plans for the future expansion of skilled and trained professionals to produce timber house in Brazil. This strategy could contribute to reduce sectoral gaps and to improve production volume and product quality. The main demands were in the Exact Science, particularly, 
for construction and wood industrialization.

Technical training in carpentry emerges as the main technician demand to be mitigated in this sector. There are requests for graduate and postgraduate professionals in Architecture and Engineering (Civil, Mechanical, etc.) with greater knowledge about timber and its applications (products, houses, structures, etc.). These demands should be included on future directions of Brazilian government to train people by means of the creation of new technical and higher education courses about timber and its constructions.

To supply the Wood Science under timber construction in Brazil, the creation of postgraduate courses in timber housing and wooden architecture should be considered and designed to enable any professionals directly involved and/or interested in this field. The popularization of Wood Industrial Engineering has been marked, but many producers still declared ignorance on this timely course for their development. A dissemination strategy about Timber Engineers and their competences could help in the consolidation of wood as material for manufactured products and in the greater student access to timber industrialization.

\section{REFERENCES}

Brege, S., Nord, T., Sjöström, R., Stehn, L. 2010. Valueadded strategies and forward integration in the Swedish sawmill industry: positioning and profitability in the high-volume segment. Scandinavian Journal of Forest Research 25(5): 482-493.

Buehlmann, U., Bumgardner, M., Alderman, D. 2017. Recent developments in US hardwood lumber markets and linkages to housing construction. Current Forestry Reports 3: 213-222.

Campos, B.P.F., Binoti, D.H.B., Silva, M.L., Leite, H.G., Binoti, M.L.M. 2013. Conversão de árvores em multiprodutos da madeira utilizando programação inteira. Revista Árvore 37(5): 881-887.
Chang, Y.-S., Kim, S., Son, W.-L., Jung, S.-C., Shin, H.-K., Shim, K.-B. 2017. Evaluation of greenhouse gas emission for wooden house using simplified life cycle assessment tool. Journal of the Korean Wood Science and Technology 45(5): 650-660.

Clement, C., Higuchi, N. 2006. A floresta amazônica e o futuro do Brasil. Ciência\&Cultura 58(3):44-49.

Coelho, M.R.F., Coelho, M.H. 2013. Panorama da indústria de celulose e papel no Brasil: 2001 a 2011. Floresta 43(3): 463-474.

De Araujo, V., Nogueira, C., Savi, A., Sorrentino, M., Morales, E., Cortez-Barbosa, J., Gava, M., Garcia, J. 2018a. Economic and labor sizes from the Brazilian timber housing production sector. Acta Silvatica et Lignaria Hungarica 14(2): 95-106.

De Araujo, V.A., Cortez-Barbosa, J., Garcia, J.N., Gava, M., Laroca, C., César, S.F. 2016. Woodframe: light framing houses for developing countries. Revista de la Construcción 15(2): 78-87.

De Araujo, V.A., Garcia, J.N., Cortez-Barbosa, J., Gava, M., Savi, A.F., Morales, E.A.M., Lahr, F.A.R., Vasconcelos, J.S., Christoforo, A.L. 2017. Importância da madeira de florestas plantadas para a indústria de manufaturados. Pesquisa Florestal Brasileira 37(90): 157-168.

De Araujo, V.A., Lima Jr., M.P., Biazzon, J.C., Vasconcelos, J.S., Munis, R.A., Morales, E.A.M., Cortez-Barbosa, J., Nogueira, C.L., Savi, A.F., Severo, E.T.D., Christoforo, A.L., Sorrentino, M., Lahr, F.A.R., Gava, M., Garcia, J.N. 2018b. Machinery from Brazilian wooden housing production: size and overall obsolescence. BioResources 13(4): 8775-8786.

De Araujo, V.A., Vasconcelos, J.S., Morales, E.A.M., Savi, A.F., Hindman, D.P., O’Brien, M.J., Negrão, J.H.J.O., Christoforo, A.L., Lahr, F.A.R., Garcia, J.N. 2018c. Difficulties of wooden housing production sector in Brazil. Wood Material Science \& Engineering (2018): 1-10. 
Fiorentin, L.D., Arce, J.E., Pelissari, A.L., David, H.C., Silva, P.H.B.M., Stang, M.B., Figueiredo Filho, A. 2017. Strategies for regulating timber volume in forest stands. Scientia Forestalis 45(116): 717-728.

França, M.C., Cunha, A.B., Trianoski, R., Schimalski, M.B., Rios, P.D. 2016. Produção de painéis aglomerados homogêneos a partir de fibras oversize residuais de uma indústria de MDF. Scientia Forestalis 44(111): 665-674.

Frigo, J.P., Silveira, D.S. 2012. Educação ambiental e construção civil: práticas de gestão de resíduos em Foz do Iguaçu-PR. Revista Monografias Ambientais 9(9): 1938-1952.

Ibá. 2016. Ibá 2016: relatório anual. São Paulo: Ibá, pp. 96.

Kim, S., Chang, Y.-S., Park, J.-S., Shim, K.-B. 2017. Evaluation of greenhouse gas emission for wooden house using simplified life cycle assessment tool. Journal of the Korean Wood Science and Technology 45(6): 828-835.

Kozak, R.A., Cohen, D.H. 1999. Architects and structural engineers: an examination of timber design and use in non-residential construction. Wood and Fiber Science 49: 37-46.

Kuzman, M.K., Sandberg, D. 2017. Comparison of timber-house technologies and initiatives supporting use of timber in Slovenia and in Sweden - the state of the art. iForests 10: 930-938.

Longue Junior, D., Colodette, J.L. 2013. Importância e versatilidade da madeira de eucalipto para a indústria de base florestal. Pesquisa Florestal Brasileira 33(76): 429-438.

MEC. 2019. e-MEC. Retrieved from emec.mec.gov.br/ emec/consulta-cadastro/detalhamento/d96957f455 f6405d14c6542552b0f6eb/MQ==/9f1aa921d96ca1 df24a34474cc171f61/MjY=, accessed in 1/5/2019.
O’Connor, J., Kozak, R., Gaston, C., Fell, D. 2004. Timber use in nonresidential buildings: opportunities and barriers. Forest Products Journal 54(3): 19-28.

Pang, S.-J., Lee, B., Jeong, G.Y. 2017. Insulation saving effect for Korean apartment house using cross-laminated timber (CLT). Journal of the Korean Wood Science and Technology 45(6): 846-856.

Pereira Filho, H.M., Lucena Filho, H.L. 2016. Terceirização trabalhista e a construção civil. Revista do Direito do Trabalho e Meio Ambiente do Trabalho 2(2): 209-226.

Pinheiro, R.M., Castro, G.C., Silva, H.H., Nunes, J.M. 2011. Pesquisa de mercado. Rio de Janeiro: FGV.

Qu, M., Pelkonen, P., Tahvanainen, L., Arevalo, J., Gritten, D. 2012. Experts' assessment of the development of wood framed houses in China. Journal of Cleaner Production 31: 100-105.

Raosoft. Raosoft sample size calculator. 2004. Retrieved from http://www.raosoft.com/samplesize.html, accessed in 1/5/2019.

Roos, A., Woxblom, L., McCluskey, D. 2010. The influence of architects and structural engineers on timber in construction - perceptions and roles. Silva Fennica 44(5): 871-884.

Seo, J., Jeong, S.-G., Kim, S. 2017. Thermal bridge and heat transfer analysis for each part in residential building according to construction of wood-based finishing material. Journal of the Korean Wood Science and Technology 45(3): 343-359.

Weska, A.R., Silva, A.S., Iliescu, D., Nascimento, H.M., Martins, J.L., Cerqueira, L., Neder, M.L.C., Silva, T.N., Rodrigues, Y.P. 2012. Análise sobre a expansão das universidades federais: 2003 a 2012. Brasilia: MEC, pp. 55. 